\title{
DPD (REGIONAL REPRESENTATIVE COUNCIL), AS A STATE AGENCY OF INDONESIAN STATE SYSTEM, RUNS THE AUTHORITY OF ITS ROLE AND FUNCTION TO CREATE THE EXISTENCE OF BICAMERAL SYSTEM IN INDONESIA
}

\author{
John Paulus Pile Tukan, Lita Tyesta ALW. \\ Faculty of Law, Diponegoro University \\ johntukan07091991@gmail.com
}

\begin{abstract}
DPD (Regional Representatives Council) which is the representative of the region can be a counterweight in strengthening the parliamentary system in Indonesia. Since the amendment begun, the Indonesian parliamentary system has changed from a unicameral system to a bicameral system. However, if noticed, the functions, powers and duties set forth in Article 22 D of the 1945 Constitution and Law No.22 of 2003 on the composition and position of MPR (People's Consultative Assembly), DPR (House of Representatives), DPD (Regional Representatives Council) and DPRD (Regional People's Representatives Council), there are many assumptions that whether the function of Regional Representative Council can represent regional's interests. DPD does not only serve as a counselor of regional autonomy board, and does not serve the legislature, as a country that embraces bicameral system. Bicameral is a term of representation system consisting of two chambers, which in Indonesia are known as DPR RI (House of Representatives of the Republic of Indonesia) and DPD RI (Regional Representatives Council of the Republic of Indonesia) which aims to achieve good government and the achievement of checks and balances between institutions, particularly in the legislature, which is one of the most important elements in the constitutional of the State.
\end{abstract}

Keywords:DPD, authorities in the role and function, bicameral system

\section{Introduction}

The Regional Representative Council (Dewan Perwakilan Daerah/DPD) was born as a part of the 1998 reformation demands with the aim to eliminate the centralized State implementation lasted from the Old Order era until the New Order which has significantly led to the disappointment accumulation of regional towards the central government, which is also a strong indication of the failure of the central government in managing the region as a base of the establishment of this nation. In addition, the existence of DPD is intended to : 1). Strengthening regional ties within the Unitary State of the Republic of Indonesia and strengthening national unity of all regions, 2). Increasing the aggregation and accommodation of aspirations and interests of the regions in the formulation of national policies related to the State and the Region. 3). Encouraging the acceleration of democracy, development, and regional progress in a harmonious and balanced manner.

The concept of unitary state is organized according to the principle of decentralization. decentralization in unitary state gave birth to the so called regional autonomy, granting regional 
authonomy to widest area is directed to accelerate the realization of public welfare throughb the improvement of service, empowerment and community participation. ${ }^{1}$

However, what happened after the DPD was formed and inaugurated in 2004 is that there is no significant authority that can divide the role of DPR (House of representative) in every policy, as seen from the authority granted by the 1945 Constitution of the Republic of Indonesia (UUD 1945) Article 28D.

In the article, it is clear that the constitution severely limits the authority of DPD, thus it is very limited and very weak, that it can be said that the Constitution treats DPD institution like a toothless lion. The authority of DPD only revolves around the proposal in the Draft Law (RUU) area, which is specifically only regarding regional autonomy issue. Meanwhile, DPR is very stro tong. This is different from the bicameral system in democratic countries which adopt a pres idential system such as two chambers adhered to by the United States constitution which governing the senate and the House of Representatives (DPR), which are equally strong.

The 1945 Constitution of the Republic of Indonesia (UUD Tahun 1945) affirms the functions, duties and authorities of the Regional Representative Council of the Republic of Indonesia (DPD RI) as a state institution (main state organ) in the realm of legislation adjacent to the House of representatives of the Republic of Indonesia ( $D P R R I)$. The existence of DPD has high urgency in the constitutional system in Indonesia. If viewed from the state administration, $D P D$ is also present to strengthen the parliamentary system in the legislation process. Legally, the existence of $D P D$ is stated in Law Number 22 Year 2003 regarding the Structure and Positionof $M P R$ (People's Consultative Assembly), DPR (House of Representatives), DPD (Regional Representatives Council) and DPRD (Regional House of Representatives). However, it is rarely mentioned that the duties, functions and authority of $D P D$ according to Law Number 22 Year 2003 are only subordinate to the $D P R$. The emergence of the second chamber idea is based on the desire to provide checks and balances space and creatively complement the two parliamentary institutions. At a glance, it wants to be in line with the representative model of two pure chambers (strong bicameralism system) like in America with the House of Representative $(D P R)$ and the Senate or the State Council and People's Council in Malaysia. If that is the case, DPD has legislative, supervision and budgetary rights that are quite powerful as Counterpart of $D P R{ }^{2}$

\footnotetext{
${ }^{1}$ Retno Saraswati, "The function of ideal Law in Preparation Regulation Legislation in order to Creating Equitable Regional Development”, Diponegoro Law Review Vol. 02 Number 01, April 2017, Semarang Faculty of Law.

${ }^{2}$ M.Ichsan Loulembah. Bikameral Bukan Federal. (Jakarta: Kelompok DPD di MPR RI, 2006), 139.
} 
Based on the background explanation above, in writing this journal, the author is interested to discuss about:

1. How does DPD RI as a state institution of the state administration system of the Republic of Indonesia exercise the authority in its current role and function?

2. How to actualize the existence of bicameral system in Indonesia?

\section{Discussion}

\subsection{DPD RI as The State Institutions in Administration System of the Republic of} Indonesia exercise the authority in its current role and function

The normative basis of $D P D$ constitutional authority arrangement is regulated in Article 22D paragraph (1), paragraph (2), and paragraph (3) of the 1945 Constitution. The Article 22D paragraph (1), paragraph (2), and paragraph (3) state that:

(1) The Regional Representatives Council may submit to the House of Representatives, the draft laws related to regional autonomy, central and regional relationship, the establishment and development as well as the incorporation of regions, the management of natural resources and other economic resources, as well as those related to central and regional financial balances.

(2) The Regional Representative Council participates in discussing the draft laws regarding regional autonomy; central and regional relationship; establishment, development and incorporation of regions; management of natural resources and other economic resources, as well as the balance of central and regional finances; as well as providing consideration to the House of Representatives on the draft state budget of income and

(3) The Regional Representative Council may oversee the implementation of laws concerning; regional autonomy; establishment, development and incorporation of regions; central and regional relationship; management of natural resources and other economic resources, implementation of state budget of income and expenditure, taxes, education and religion and submitting the results of its supervision to the House of Representatives for consideration to be followed up.

From the basis of $D P D$ 's constitutional authority regulation, $D P D$ has 3 (three) functions which are functions of legislation, considerations and supervision. The three functions of $D P D$ are limited, because the implementation of these functions is limited to certain areas that are the authority of $D P D$. Arrangement of $D P D$ function is also described in Article 223 paragraph (1) of Law No. 17 of 2014, DPD has functions of: 
a. submission of proposals to $D P R$ on draft of law related to regional autonomy, central and regional relations, the establishment and development and incorporation of regions, the management of natural resources and other economic resources, as well as those related to central and regional financial balances;

b. participation in the discussion of draft of law related to regional autonomy, central and regional relations, the establishment and development and incorporation of regions, the management of natural resources and other economic resources, as well as those related to central and regional financial balances;

c. consideration provision to $D P R$ on the draft of law on state budget of income and expenditure and draft of law related to taxes, education and religion; and

d. implementation supervision of the law on regional autonomy, central and regional relations, the establishment and development and incorporation of regions, the management of natural resources and other economic resources, the implementation of the state budget, taxes, education and religion.

Furthermore, the regulation of $D P D$ 's authority which is arranged in conjunction with the duties of $D P D$ as regulated in Article 224 up to Article 226, which are parts of the DPD function. As a continuation of the three functions mentioned above, $D P D$ has general duty and authority as regulated in Law Number 17 Year 2014, Article 224 paragraph (1) which affirms as follows:

a. able to submit to $D P R$, the draft of laws relating to regional autonomy, central and regional relations, the establishment and development and incorporation of regions, the management of natural resources and other economic resources, as well as those related to central and regional financial balances;

b. participate in discussions with the $D P R$ and the President on the draft of laws relating to the matters referred to in letter aparticipate in discussions with $D P R$ and the President on the draft of law submitted by the President or $D P R$, regarding the matters referred to in letter;

C. provide consideration to $D P R$ on the draft of laws on the State Budget and the draft of laws regarding taxes, education and religion;

d. able to supervise the implementation of laws on regional autonomy, central and regional relations, the establishment and development and incorporation of regions, the management of natural resources and other economic resources, the implementation of the state budget, taxes, education and religion;

e. submit the supervision results over the implementation of the law on regional autonomy; establishment, development and incorporation of regions; central and regional relationship; 
management of natural resources and other economic resources, implementation of state budget of income and expenditure, taxes, education and religion and submitting the results of its supervision to the House of Representatives for consideration to be followed up;

f. receive the examination results of the State's finances from $B P K$ (Finance Audit Board) as a material of consideration for $D P R$ regarding the draft of laws relating to the State's budget;

g. provide consideration to $D P R$ in the election of $B P K$ members; and

h. participate in the preparation of national legislation programs related to regional autonomy, central and regional relations, the establishment and development and incorporation of regions, the management of natural resources and other economic resources, as well as those related to central and regional financial balances

Furthermore, it is continued in paragraph (2) which affirms that: in carrying out supervisory duties as referred to in paragraph (1) letter e, $D P D$ members may hold meetings with local governments, DPRDs and elements of the community in their constituencies.

Based on the $D P D$ function as described above, $D P D$ has constitutional authority based on the 1945 Constitution and further regulation based on Law No. 17 of 2014. As a state institution, $D P D$ has a very important position related to its function. $D P D$ which can carry out its function is the existence of $D P D$ as a state institution, because its function describes the existence of a certain state institution.

Related to the implementation of $D P D$ function, then the problem is related to zelfstandigheid ${ }^{3}$ that is the independence authority or the full function and or the determining function of the representative institution (DPD), either from the aspect of planning, preparation, discussion, to decision making. This is also related to the authority of $D P D$ in carrying out the functions of legislation, functions of consideration, and supervisory functions. Therefore, the assessment of DPDzelfstandigheid is related to the function of legislation including the function of consideration and supervisory function.

The legislative function of $D P D$ based on Article 223 of Law Number 17 Year 2014 when compared to the substantive arrangement of the same norm as formulated in Article 41 letter (a) of Law Number 22 Year 2003, it only relates to certain legislative areas of. In the description of Article 41 letter (a), it states that: "The meaning of certain legislative areas in terms of the function of proposing and discussing the draft of laws is related to the draft of laws regarding regional

\footnotetext{
${ }^{3}$ Abd. Rahman. Kedudukan Dan Kewenangan Dewan Perwakilan Daerah (DPD) Dalam Sistem Perwakilan Indonesia: Summary of Dissertation, PhD Thesis. (Surabaya: University of Airlangga, 2006), 33.
} 
autonomy, central and regional relations, the establishment and development and incorporation of regions, the management of natural resources and other economic resources as well as central and local financial considerations. Whereas in terms of the function of providing consideration to the draft of laws, it is related to the budget of state income and expenditure, and the draft of laws relating to taxes, education, and religion".

Considering the arrangements as defined in Law Number 17 Year 2014, there are functions of legislation, considerations, and oversight. The legislative function of $D P D$ is related to 3 (three) task areas, namely: 1) proposing the draft of law; 2) discussing the draft of law; and 3) providing considerations to the draft of law. The supervisory function relates to the supervision over the implementation of the law, whereas the budget function relates to the consideration of the State Budget draft, the draft of laws related to taxes, education, and religion. ${ }^{4}$

The arrangement described above indicates that the scope of the first and second task areas includes the draft of laws related to regional autonomy, central and regional relations, the establishment and development and incorporation of regions, the management of natural resources and other economic resources, as well as those related to central and regional financial balances. While the scope of the third task field is limited to providing considerations to the draft of law related to taxes, education, and religion. All $D P D$ duties mentioned above are submitted to $D P R$ as the final decision maker.

In Law no. 17 Year 2014 on the composition and position of the MPR, DPS, DPD, and DPRD, the arrangement of relationship of DPR and DPD in the legislative function is overly regulated in the Code of Conduct of DPR. Since Law No. 17 Year 2014 delegates DPR and DPRD relationship arrangement in the formulation of the Code of Conduct of DPR, the the Code of Conduct of DPD only governs the preparation and submission of draft of laws derived from the DPD and does not establish arrangements on relations of DPD and DPR in discussing the draft of laws that become the authority of DPD.

Meanwhile, the Code of Conduct of DPR regulates in detail the discussion of the draft of laws that comes from DPD. The limited authority of DPD in the legislative function in Article 22D paragraphs 1 and 2 of the 1945 Constitution is further restricted by Law No. 17 Year 2014 and the Code of Conduct of DPR 2016/2017. In addition, in practice, DPR has never followed up on the draft of law comes from DPD. Therefore, the role of DPD is increasingly invisible in the legislative function. Observing the limitations of that authority, the strengthening of the legislative function of DPD becomes inevitability. Legally, the strengthening can be done by continuing the 
amendment to the 1945 Constitution. However, it becomes difficult to strengthen the legislative function of DPD without touching the 1945 Constitution. The strengthening of the legislative function should be done by comprehensively reorganizing the legislative function in the system of Indonesian government. DPD may not be fully involved in discussing the bill as the DPR, but to build the checks and balances, DPD should be given the space to correct and/or reject the bill which has been approved by DPR.

On the other hand, DPD's involvement occurs only in the initial process. At that stage, the legislative function takes place during the process undertaken by DPR, President, and DPD. However, when the process is on the stage of further discussion and collective approval, DPD is no longer involved because the legislation process returns to DPR and the President as stated in Article 20 paragraph 2 of the 1945 Constitution. Thus, DPD is expected to be able to contribute politically in voicing the interests of regional part eventhough its role in parliament is not in line with what the region wants since the role given by the constitution is very small.

The presence of the DPD should provide a solution to the centralized political system that reigns over the last five decades. However, the existence of DPD does not have the expected function because it is nothing more than merely an accessory of democracy within the representation system. This can be seen from the articles that regulate the authority of DPD.

There are visible discriminatory elements in the authority of DPD, particularly with the expectations of public to participate widely and competitively.With regard to the above problems, Mahfud MD explains that it is not true that the idea of bicamarelism is associated with federalism and government systems of a State.

The Regional Representative Council (DPD) is a regional representative body which is a state institution and has functions of: (a) submit a proposal, participate in deliberations and provide consideration related to particular legislation field; (b) supervision over the implementation of certain laws. ${ }^{5}$

On the other hand, DPD has the Tasks and Authorities regulated in Article 224 paragraph (1) and (2) of Law no. 17 year 2014 on the MPR, DPR, DPD, and DPRD, which are as follows:

a. DPD has duties and authority:

1) Able to propose to DPR, a draft of law regarding regional autonomy, central and regional relations, the establishment and development and incorporation of regions, the management of natural resources and other economic resources, as well as those related to central and regional financial balances;

\footnotetext{
${ }^{5}$ Huda, Ni’Matul, Hukum Tata Negara Indonesia, (Jakarta:PT. RajaGrafindo Persada,2005), 181.
} 
2) To participate in the discussion with DPR and the President on the draft of law related to the matters referred to in letter a;

3) To participate in the discussion with DPR and the President on the draft of law submitted by the President or DPR, related to the matters referred to in letter a;

4) To provide consideration to DPR on the draft of law regarding the State Budget and the draft of laws relating to taxes, education and religion.

\subsection{Actualizing The existence of Bicameral System in DPD RI in Indonesia}

The bicameral parliament contains a basic conception of parliament which has three main functions of parliament: legislative, supervisory, and budgetary. The existence of a two-chamber system within a single parliament itself was created to accommodate the spirit of check and balance within the parliament itself. From the experience, bicameral system can prevent negative and executive collusion.

Expert of Constitutional Law, Prof. Dr. JimlyAsshiddiqie, explains that there are two main reasons which are often used to apply this bicameral system:

1. There is a need to ensure a more stable equilibrium,

2. The desire to ensure the government system to really run more efficiently and at least more smoothly. ${ }^{6}$

Giovanni Sartori divides the bicameral parliamentary system into three types: namely:

1. Weak bicameral system (asymmetric bicameralism or weak bicameralism or soft bicameral), which is when the power of one room is much more dominant over other rooms.

2. Strong bicameralism system (symmetric bicameralism or strong bicameralism), which is when both two rooms are almost as strong.

3. Perfect Bicameralism, which is when the strength between the two rooms is really balanced. $^{7}$

Furthermore, Sartori classifies the bicameral based on the composition or structure of membership between the two chambers, which are: (1) bicameral of the same element (similiar bicameralism); (2) bicameral which the elements are somewhat different (likely bicameralism); (3) bicameral which the elements are very different element (differentianted bicameralism). ${ }^{8}$

\footnotetext{
${ }^{6}$ Jimly Asshidiqie, Perkembangan dan Konsolidasi Lembaga Negara Pasca Reformasi, (Jakarta: Sekjen MK, 2006), 12.

${ }^{7}$ Giovanni Sartori, Comparative Constitutional Engineering, (Jakarta, 1997), 184.

${ }^{8}$ Ibid., 185
} 
Based on the classification made by Giovanni Sartori, the ideal bicameral should lead to a combination of strong bicameralism with likely bicameralism. This is to shift the bicameral toward unicameral and to minimize the deadlock of the parliament's work process.

After the above discussion about a brief description of bicameral system, thus this sub will slightly discuss about the application of bicameral system in Indonesia. Nowaday, the bicameral system in Indonesia is already implemented. This is hinted by the establishment of DPD and the structure of constitutional system after the amendment of the 1945 Constitution of the Republic of Indonesia. In the current constitutional dynamic, $D P R$ and $D P D$ are required to be harmonious and play a role of mutual supervision. This is a part of the expected of the bicameral system implementation. However, in fact, the system is currently still considered as not fully visible, or the state administration experts usually call it soft bicameral. SaldiIsra denied that our parliament embraces soft bicameralism. According to him, aside from the authority possessed by the $M P R$, in addition to the constitutional authority of $D P R$ and $D P D$, Indonesia adopts a three-room parliamentary system (trikameral). Even Sri Soemantri mentioned that our parliamentary system uses the concept of "no-no". It is because he thinks the resulting parliamentary system is not unicameral, nor it is bicameral, but tends to be tricameral. ${ }^{9}$

The embrace of a bicameral of $M P R$ proven with the direct election of $D P R$ and $D P D$ by the people in the 1945 Constitution of the Republic of Indonesia reflects that we are entering a democracy that must all be chosen. The authority of $D P R$ differs from the authority the $D P D$, the restructuring of $M P R$ and the reconstruction towards the bicameral legislator is about to clarify the type of parliament in unicameral or bicameral typology.

The bicameral system is considered by many to be the embodiment and essence of TriasPolitica. The existence of bicameral system is intended to minimize the authority that is too broad for the institution and maximize the inter-agency supervision function. One way of limiting and controlling that power is by using a system of mutual supervision and balance among various institutions.

\section{Conclusions}

DPD, in its status as a state institution which is a regional representative institution, institutionally has the same position as other state institutions, such as MPR and DPR. From this

\footnotetext{
${ }^{9}$ Saldi Isra, "Penataan Lembga Perwakilan Rakyat : Sistem Trikameral di Tengah Supermasi Dewan Perwakilan Rakyat," Journal of Costitution Vol.1: No. 1, (July 2004): 129-132.
} 
position, DPD is not functional on the position and the relations. In relation to DPR and MPR, the position of DPD as stipulated in the 1945 Constitution, is not in accordance with the idea of its forming. The reformation of the Indonesian state administration structure to strong bicameralism is not established in the 1945 Constitution. Based on the formulation of Article 2 paragraph (1) of the 1945 Constitution, the Indonesian state administration system has a soft bicameralism system.

Looking at the weaknesses of the Regional Representative Council, the authors argue to re amend the 1945 Constitution, which the aim is to strengthen the existing bicameral system, so that DPD has the same role as DPR, which are both have legislative function, so that there will be no imbalances in the existing bicameral parliamentary system in Indonesia in the future. DPD can design and legitimize what to be rights of DPD in stating the interests in the region, so that the development/progress in the region can be actualized and implemented as expected by the Indonesian nation.

Based on the conclusions, recommendations in this research: (1) at the beginning of the amendment of the 1945 Constitution, many people considered that a strong bicameralism system could lead the Unitary State of the Republic of Indonesia into a Federal state. However, the reality is now that checks and balances of a state institution shall be implemented to improve a system of mutual supervision and there is no more dominant institution; (2) There is a need of an amendment to Article 2 paragraph (1) and Article 22D of the 1945 Constitution related to the affirmation of representative system in Indonesia as "strong bicameral" or "soft bicameral" with the existence of DPD, which is a regional representative institution acted as a State institution; and (3) this research can be used as a basis for next research. 


\section{References}

Abd. Rahman. (2006). Kedudukan Dan Kewenangan Dewan Perwakilan Daerah (DPD) Dalam Sistem Perwakilan Indonesia: Ringkasan Disertasi. Ph.D Disertation. Universiti Airlangga Surabaya.

Giovanni Sartori. (1997). Comparative Constitutional Engineering. Jakarta.

Huda, Ni'Matul. (2005).Hukum Tata Negara Indonesia. Jakarta: PT. RajaGrafindo Persada

Jimly Asshidiqie. (2006). Perkembangan dan Konsolidasi Lembaga Negara Pasca Reformasi. Jakarta: Sekjen MK

M.Ichsan Loulembah. (2006).Bikameral Bukan Federal, artikel DPD dan Perwakilan Politik Daerah, Jakarta: Kelompok DPD di MPR RI.

Retno Saraswati, The function of ideal Law in Preparation Regulation Legislation in order to Creating Equitable Regional Development, Diponegoro Law Review Vol 02 Number 01, April 2017, Semarang Fakulty of Law, Diponegoro Univercity.

Saldi Isra. (2004). Penataan Lembga Perwakilan Rakyat: Sistem Trikameral di Tengah Supermasi Dewan Perwakilan Rakyat. Jurnal Konstitusi Vol.1: No. 1, 129-132.

Undang Undang Dasar Negara Republik Indonesia Tahun 1945

Undang Undang No. 17 tahun 2014 tentang MPR, DPR, DPD, dan DPRD

Undang-Undang Nomor 12 Tahun 2011 tentang Pembentukan Peraturan Perundang-undangan 